\title{
A STUDY ON DETERMINING THE PROBLEMS OF FIRMS IN TURKISH LOGISTICS SECTOR
}

\author{
Filiz Çopuroğlu ${ }^{1}$, Reyhan Sarıçiçek ${ }^{2 \star}$, Mehmet Aytekin ${ }^{3}$ \\ ${ }^{1}$ Lectuer, Gaziantep University, TURKEY, filizcokay@gantep.edu.tr \\ ${ }^{2}$ Lecturer, Gaziantep University, TURKEY, reyhans@gantep.edu.tr \\ ${ }^{3}$ Asst. Prof., Gaziantep University, TURKEY, aytekin@gantep.edu.tr \\ ${ }^{*}$ Corresponding Author
}

\begin{abstract}
Logistics, which has been the sum of the responsibility that originates from the resource assets, continues with the order of the customers and the producer companies which supply the product during the time the customers use the product. In conducting these activities, the most effective way to succeed in logistics is to ensure that correct product access is provided to the right customers. For the fact that logistics is improving in the world, it is one of the sectors showing rapid improvements in Turkey as well.

Turkey, due to its location, has political and economic advantages and it is at a place where it provides continuity of world trade. It is obligatory to use this strategic advantage and make commercial works. Looking from this perspective, logistics activities, besides being just commercial acts in Turkey, faced with the fact that they are activities that are also beneficial for bringing more income for the state's economy, should be spread to more areas.

This study has been conducted to examine the current situation and development of the logistics industry, in order to identify the problems of firms in this sector and to assist in the significance of the sector by developing solutions to these problems. In this context, logistics qualities and importance of logistics, logistics management, the situation of logistic activities in Turkey, Turkey's strengths and weaknesses in the logistics sector have been discussed. In addition to that customer service problems, problems encountered in transportation activities, storage problems, transportation and packaging problems, problems in purchasing and customs liquidation activities were examined. The research has been conducted by consulting 7 representatives from the leading companies in Turkey's logistics sector and it was conducted with qualitative method.

According to the analysis of study, the results have been evaluated with in the progress in logistics. The framework will help to increase the logistic potential of Turkey by identifying the problems of the sector and eliminating the deficiencies by developing solutions for these problems.
\end{abstract}

Keywords: Logistics, logistics sector problems, the logistics sector in Turkey 


\section{INTRODUCTION}

The word logistics comes from the Ancient Greek word 'logisticos' which means calculation science or skill in calculation (Koban et al, 2007: 35). Logistics; in its most recent definition is, accessibility of the material with right amount, the right place and the right price. The development of the logistics depends on the logistical capabilities and skills of the countries. Logistic evaluations which have been based on country and region are important because some regions of the world have excellent logistical facilities that have a significant share of success, while others lack these features. Region evaluation in logistics is based on geographical, physical and institutional infrastructure. Such assessments shed light on the investments and arrangements necessary for the development of logistics (Tanyaş, 2006). The reason many global brands can be permanent in international markets is due to their effective logistics management that targets customer satisfaction and low costs (Tuna, 2001; 194). For this reason, the logistics sector has been significant globally. The rapid development and growth trend in the sector brings some changes and innovations in the types of activities and business processes. During the establishment of the national and international logistics chain, it has established new activities and services in the sector such as intermodal transport, combined transport, multiple transport, warehouse and stock management, third party logistics operations, customs and insurance management. All of these activities and services need to be presented at the lowest possible cost in terms of quality, speed, integration and scale economy (Aydın and Öğüt, 2008a; 1441). Each logistics activity is an area that will change the costs, these can affect other activities. For this reason, all logistics activities must be systematically managed in order to gain competitive advantage; this is the main theme of logistics management. Strategic logistics management encompasses the entire operating system between the customer and the supplier, including competitive advantage and vertical integration (Gürdal, 2006: 12). Logistics activities carried out today can be likened to a chain formed by cyclic structure. The first ring of the chain can be the last ring at the same time. Logistics begins with the conception of the need in the owner's mind and ends with the process of removing the product and recycling (Gültaş and Yücel, 2015: 76).

The logistics sector, which has been developing since the developed countries all over the world integrated, has made its infrastructure in Turkey with investments in land, air, sea, and railway and combined transportation fields between 1980s and 1990s. The logistics sector in Turkey, which diversifies and specializes its services in parallel with similar applications in the world, has become a dynamic sector that, by the year 2000, has left the early phase and continued to cooperate in domestic and international companies it continuously improves the quality of its overseas branches (Babacan, 2003: 10). In addition to logistics and transportation, storage, customs, insurance, packaging and value added services, order and inventory management, and inspection and surveillance activities need to be coordinated. The growth of the logistics industry entirely depends on the growth of the industry and trade sectors. On the other hand, the logistics sector is growing more rapidly than Turkey's financial growth rate. The main reason for this is the increase in outsourcing. (Tanyaş, 2016:1).

\section{METHOD}

This study is a qualitative research aiming to determine the current status and problems of the Turkish logistics industry. The aim of qualitative research is to be able to comprehend a particular event in its entirety and in its natural environment, all the way to the finest detail and in the most concrete way to reach that kind of understanding and explanations and discoveries (Gür, 2009: 3). Qualitative research has been done for the purpose of describing the depth and richness of the data. In this research, case analysis (statues study, sample case study) method which is one of the qualitative research designs was used. The purpose of the case study is to draw conclusions about a particular case. This research design has been used because the situation regarding Turkey's logistics sector and its problems have been revealed in this study.

Turkey's logistics firms constitute the universe of research. In the study, interviews were conducted with 7 of logistics firms in order to examine Turkey's logistics sector and its problems. These companies are from the leading companies in the sector and they are capable of reflecting the general image of the sector. According to the "Fortune 500 Turkey" survey, 3 of these 7 firms are among the top 500 firms in Turkey and these firms are among the 14 largest logistics firms in Turkey in the sub-sector rankings. Company names will be kept confidential in order to comply with ethical rules.

The interview questions used in the research were prepared by the researchers, via scanning the related field and taking the necessary expert opinions. Front implementation was done then the actual applications were activated. During the interview, prepared questions were asked to the firm. Interviews were conducted face to face in advance through appointment from the company. Appropriate environments have been chosen to ensure that interviews are sound. Each interview lasted approximately 20-25 minutes. Detailed information was collected. The interviews were recorded. 
The interview method, which is one of the qualitative data collection methods, has been used in the research. The data were collected by a semi-structured interview form consisting of 11 questions prepared by the researchers for this research. Semi-structured interview techniques were applied in the interviews. The interview was conducted in face-to-face interviews and the participant's comments on the topic were written. The interview data were examined one by one, evaluated together with the notes related to the interview, and the codes were given and reported. Descriptive and content analysis techniques were used in the analyses. In the descriptive analysis, it is aimed to summarize and interpret the obtained data according to the previously determined theme (Yıldııım and Şimşek, 2008:227). Categorical and frequency analysis techniques were used in content analysis. Frequency analysis is to reveal the frequency of units and items in a numerical, percentage and proportional manner. Categorical analysis is the division of a given message into units, and then these units are grouped into categories according to certain criteria (Bilgin, 2006: 18-19). The interviews with the companies have been tried to be projected as neutral as possible. The data obtained in order to be able to create a holistic picture about the subject investigated is supported by the participant confirmation. Appropriate environments have been chosen to ensure that interviews are sound. Shortly before the meeting, employees were briefed on the content of the study. Attempts were made to collect detailed information during the interviews. Findings are consistent with the conceptual frameworks and theories that are consistent, meaningful, and generated in the past. For domestic credibility, direct quotations from the interviews were made. At the end of the interview, the participant was asked about the fact that his or her perception accurately reflects the data transmitted by the investigator, and thus external reliability is proved.

\section{RESEARCH FINDINGS AND FINDINGS INTERPRETATION}

The findings of the study to determine the logistics sector and its problems in Turkey are summarized below. Companies participating in the research use motorway, air, sea and rail transport modes in truth their logistics activities. The percentages of usage of the transportation modes of the companies are shown in table 1 below:

Table 1. Use of Transportation Modes of Investigated Companies

\begin{tabular}{|c|c|c|c|c|}
\hline Firms & $\begin{array}{c}\text { Highway } \\
\text { transport }\end{array}$ & $\begin{array}{c}\text { Sea } \\
\text { Transportation }\end{array}$ & $\begin{array}{c}\text { Airway } \\
\text { Transporting }\end{array}$ & $\begin{array}{c}\text { Railway } \\
\text { Transportation }\end{array}$ \\
\hline 1 & $\% 58$ & $\% 20$ & $\% 20$ & $\% 2$ \\
\hline 2 & $\% 70$ & $\% 15$ & $\% 5$ & $\% 10$ \\
\hline 3 & $\% 70$ & $\% 25$ & $\% 5$ & $\% 2$ \\
\hline 4 & $\% 67$ & $\% 23$ & $\% 8$ & \\
\hline 5 & $\% 40$ & $\% 30$ & $\% 30$ & \\
\hline 6 & $\% 90$ & $\% 10$ & & \\
\hline 7 & $\% 100$ & & & \\
\hline
\end{tabular}

Firms prefer mostly motorway to perform their logistics activities. For international transportation activities, they prefer mostly sea freight transportation. Due to the high cost of air transportation, it is used less than the land and sea transportation. Firms prefer railway transportation less due to the lack of railway infrastructure.

Table 2. Problems Experienced with other Companies

\begin{tabular}{|l|l|c|}
\hline Main Theme & Sub Themes & F \\
\hline \multirow{4}{*}{$\begin{array}{l}\text { Problems experienced with companies that are } \\
\text { served }\end{array}$} & Material Issues & 4 \\
\cline { 2 - 3 } & Untrained Staff & 4 \\
\cline { 2 - 3 } & Failure to meet expectations & 3 \\
\cline { 2 - 3 } & Failure to Achieve Continuity & 2 \\
\cline { 2 - 3 } & Experience and lack of sectoral knowledge & 1 \\
\hline
\end{tabular}

When table 2 is examined, the problems faced by the firms that participate in the research are respectively; material issues, untrained personnel, failure to meet expectations, lack of continuity, lack of experience and sectoral knowledge. With the firms that are provided with logistics services, the problems arise from mostly financial matters and untrained personnel. 
Table 3. Problems in Transportation Activities

\begin{tabular}{|l|l|c|}
\hline Main Theme & Sub Themes & F \\
\hline \multirow{4}{*}{$\begin{array}{l}\text { Problems in } \\
\text { Transportation }\end{array}$} & No coordination between transport modes & 4 \\
\cline { 2 - 3 } Activities & Capacity and quality deficiencies in all transportation infrastructure & 4 \\
\cline { 2 - 3 } & Lack of information about legal regulations & 4 \\
\cline { 2 - 3 } & Short-term visa requirements, document inflation and bureaucracy & 3 \\
\cline { 2 - 3 } & Railway networks are neglected and inadequate & 2 \\
\cline { 2 - 3 } & 75\% of our import/ export shipments are carried by foreign flagged vessels & 2 \\
\cline { 2 - 3 } & High cost of land transportation & 1 \\
\cline { 2 - 3 } & Delays due to the old cranes in the harbor & 14 \\
\hline
\end{tabular}

The problems and frequencies experienced in the transportation activities of the companies are given in table 3 . When table 3 is examined, the problems experienced in transportation activities are sorted by; lack of coordination between transport modes, lack of capacity and quality in all transportation infrastructure, lack of information about legal regulations, short term visa periods, inflation and bureaucracy during visa procedures, railway networks are neglected and inadequate, $75 \%$ of our import / export loads are transported by foreign flagged vessels, the high cost of road transportation fees, and the delays due to the old cranes in the port.

Table 4. Problems in Storage Operations

\begin{tabular}{|l|l|c|}
\hline Main Theme & Sub Themes & $\mathbf{f}$ \\
\hline \multirow{4}{*}{$\begin{array}{l}\text { Problems in Storage } \\
\text { Operations }\end{array}$} & High rent & 5 \\
\cline { 2 - 3 } & Use of general purpose or faulty warehouses & 3 \\
\cline { 2 - 3 } & No flexible growth opportunities & 3 \\
\cline { 2 - 3 } & Inadequate product dispatch and acceptance points & 2 \\
\cline { 2 - 3 } & Transportation Problem & 2 \\
\cline { 2 - 3 } & Inadequate storage space & 1 \\
\hline \multicolumn{1}{|c|}{ Total } & 16 \\
\hline
\end{tabular}

When the table 4 is examined, the problems experienced in storage activities are sorted by; High rents, the use of general purpose and faulty warehouses, no flexible growth opportunities, the inadequacy of product referral and acceptance points, the transportation problem and the inadequacy of warehouse area.

Table 5. Problems in Handling and Packaging Activities

\begin{tabular}{|l|l|c|}
\hline Main Theme & Sub Themes & $\mathbf{f}$ \\
\hline \multirow{4}{*}{$\begin{array}{l}\text { Problems in Handling and } \\
\text { Packaging Activities }\end{array}$} & Packaging does not conform to product specifications & 4 \\
\cline { 2 - 3 } & Damage during loading and unloading & 4 \\
\cline { 2 - 3 } & Packing is not protected during transportation, distribution and rafting & 3 \\
\cline { 2 - 3 } & The lack of qualified staff & 2 \\
\cline { 2 - 3 } & Use of inappropriate handling system & 2 \\
\cline { 2 - 3 } & The excess of standby & 2 \\
\cline { 2 - 3 } & Less use of assistive devices & 1 \\
\hline \multicolumn{1}{|c|}{ Total } & 18 \\
\hline
\end{tabular}

The problems and frequencies experienced in the handling and packaging activities of the companies are given in table 5 . When it's examined in, the problems experienced in handling and packaging activities are sorted by; packaging does not conform to product specifications, damage during loading- carryingunloading, lack of protection during transportation, distribution and raft holding, lack of qualified personnel, use of inappropriate handling system, surplus waiting, and less use of assistive devices can be seen as sub themes. 
Table 6. Issues encountered during the procurement process

\begin{tabular}{|l|l|l|}
\hline Main Theme & Sub Themes & $\mathbf{f}$ \\
\hline \multirow{3}{*}{$\begin{array}{l}\text { Issues encountered } \\
\text { during the procurement } \\
\text { process }\end{array}$} & Suppliers' shortcomings in after sales service and warranty & 4 \\
\cline { 2 - 3 } & Use only specific brand and supplier specifications & 3 \\
\cline { 2 - 3 } & inability to understand the expertise to purchase & 3 \\
\cline { 2 - 3 } & No suitable materials and technology to meet the need & 2 \\
\cline { 2 - 3 } & Delivery delays and lost shipments & 2 \\
\hline \multicolumn{1}{|c|}{ Total } & 14 \\
\hline
\end{tabular}

The problems and frequencies that the companies encounter in the procurement process are given in table 6. As seen in table 6 , the problems experienced in the purchasing activities of the companies participating in the survey are displayed. Suppliers' lack of after-sales services and warranty, the use of only certain brand and supplier specifications, the lack of expertise in making purchasing agreements, the lack of appropriate materials and technology to meet their needs, delayed deliveries and lost shipments are displayed.

Table 7. Problems in Customs Clearance

\begin{tabular}{|l|l|c|}
\hline Main Theme & Sub Themes & $\mathbf{f}$ \\
\hline \multirow{4}{*}{$\begin{array}{l}\text { Problems in Customs } \\
\text { Clearance }\end{array}$} & Slow execution of transactions & 7 \\
\cline { 2 - 3 } & Late arrivals of exit records & 4 \\
\cline { 2 - 3 } & Need for modernization of border Gates & 3 \\
\cline { 2 - 3 } & Changing the description of the goods & 2 \\
\cline { 2 - 3 } & High warehouse fees & 2 \\
\cline { 2 - 3 } & Transitional document issue & 2 \\
\cline { 2 - 3 } & Power of Attorney and application uniformity & 1 \\
\cline { 2 - 3 } & Lack of an effective auditing system for fighting corruption & 1 \\
\cline { 2 - 3 } & Exports made from warehouses & 1 \\
\cline { 2 - 3 } & Transit shipments to be initiated by the last customs officer & 1 \\
\hline
\end{tabular}

The problems and frequencies experienced in the customs clearance activities of the companies are given in table 7. When table 7 is examined, the problems experienced in customs activities are sorted by as follows; slow execution of transactions, late arrivals of exit records, need for modernization of border gates, changing the description of the goods, high warehouse fees, transitional document issue, power of attorney and application uniformity, lack an effective audit system for fighting corruption and other unlawful acts, exports made from warehouses, transit shipments to be initiated by the last customs officer constitute all sub themes.

Table 8. Preparations and innovations initiated to compete in the sector and optimize the logistics system

\begin{tabular}{|l|l|c|}
\hline Main Theme & Sub Theme & F \\
\hline \multirow{2}{*}{$\begin{array}{l}\text { Preparations and } \\
\text { innovations initiated to } \\
\text { compete in the sector }\end{array}$} & $\begin{array}{l}\text { The foundation of human resources for professional management and } \\
\text { consultancy services }\end{array}$ & 7 \\
\cline { 2 - 3 } $\begin{array}{l}\text { and optimize the } \\
\text { logistics system }\end{array}$ & Reducing the risk of errors & 7 \\
\cline { 2 - 3 } & Creating and constantly updating information technology infrastructure & 6 \\
\cline { 2 - 3 } & Analysis of the supply chains of the sectors & 4 \\
\cline { 2 - 3 } & Investing in fixed assets & 27 \\
\hline \multicolumn{2}{|c|}{ Total } & 27 \\
\hline
\end{tabular}

The preparation/innovation initiated by the companies to optimize the logistic system and to be able to compete and their frequencies are given in Table 8 . When Table 8 is examined, the preparations and innovations of firms in order to compete in the sector and optimize the logistics system are as follows; the foundation of human resources for professional management and consultancy services, reducing the risk of errors, creating and constantly updating information technology infrastructure, analysis of the supply chains of the sectors, investing in fixed assets are the sub themes. 


\section{RESULTS}

In this research, Turkey's leading firms have been interviewed to investigate Turkey's logistics sector and sectorial problems. The most common type of transportation used by companies is land transportation and land transportation is followed by sea transportation. The airline is only valid for special products due to cost and integration problems. Road and sea freight transport is preferred in situations where there is no time constraint. However, the railway is the least preferred system. The lack of maintenance and inadequacy of railway networks makes this transportation model, one of the most important transport modes for logistics, unusable.

The problems are dealt with according to the activities with in the research. Firms' problems with their customer relationships are mostly caused by financial issues. This may be due to differences between the pricing requested by the customer and the pricing offered by the companies, as well as differences in the payment terms requested. To overcome this problem, customers can be made aware of the average sector prices and different payment options can be developed. Firms' training of customer relations and the improvement of attitudes and behaviours of employees and managers can reduce the difficulties experienced by personnel. Customer relationship training can be viewed as an investment rather than a cost. With the latest training methods and planned trainings, employees can be improved and the performance of the business can be improved. By understanding the concept of quality and increasing the number of loyal customers, starting from top management, we can build a faith to make quality service and $100 \%$ quality production in all stages of the organization and develop the total quality spirit that adopts continuous improvement. It may be necessary to work out what the expectations of the customers are, what the customers are pushing to buy, and what needs to be done to make them continuous customers.

Sectorial developments and innovations can be closely monitored. The lack of coordination between modes of transport can reduce the speed and capacity of logistics activities. Working to ensure that maritime and airports are integrated with all other transport types can provide significant benefits. In order to overcome capacity shortages and quality deficiencies in transportation infrastructure, it is necessary to provide modernization of all transportation means, establishment of infrastructure for intermodal transportation, connection of ports, industrial zones and companies connected to international railway transportation network, development of railway transportation and establishment of modern logistic villages.

Firms frequently have problems with lack of information about legal regulations in transport activities. Changes in legal arrangements can be closely monitored and trainings can be organized for the staff. The short duration of visa periods and the excess of the bureaucracy experienced during visa issuance are among the problems experienced in transportation activities. The problem of getting a visa is preventing export marketing work and this affects exports negatively. Visa issues can be addressed to the competent authorities of the country in question. Since it is advantageous to transport long distance, heavy and high cargoes in railways, the use of railroads may be more appropriate, especially in the case of international carriage and combined carriage in transit carriage. Railway infrastructure can be improved, existing railway networks can be maintained and railway investment rates can be increased. Port development and quality control, storage, maintenance / repair, assembly, packaging, separation, consolidation, distribution, etc. may need to be brought to a level that can provide logistics services including value-added transactions. It may be useful to ensure that port tariffs are brought to the appropriate level in the export promotion direction. Delays due to the old cranes in the harbour can be experienced. This problem can be solved with the necessary investments and renewals.

The firms that provide logistic services mostly suffer in storage activities due to high rents. High rental rates increase the logistics can put companies in trouble. Eliminating this problem may reduce the cost of building the warehouse, thus reducing the cost of the renting warehouse. For this purpose, municipalities can produce new storage areas. Development plans can be made to build new warehouses. Warehouses can be built according to the specifications of the product to be stored. Contemporary, high-ceiling, flexible growthcapable warehouses can be constructed to store the products that large vehicles carry without entering the city. As a solution to transportation problems, storage services may need to be gathered in certain areas in some order. Distribution channels can be created from the warehouses by ring trips with small vehicles and more products can be transported in shorter routes by combining distributions. Thus, both storage costs can be reduced and productivity and cost advantages can be achieved in distribution networks.

If high-quality and over-priced products are transported with low-quality packaging, the products may be damaged, deteriorated, the prices of the products may be reduced, or all may be rejected by the buyer. The temperature of the packaging, the humidity, the air that must be around the product, the durability of the package, the cost, the availability, and the requirements of the buyer risks can be minimized. Work on loading and unloading of products into vehicles should be done taking into account the characteristics of the 
product. Care should be taken to protect the packaging from external influences before anything else. In the design of material handling equipment, it may be necessary to consider the capabilities and limits of the human being, to make the equipment redundant and heavy, to manually remove the work and to maintain business productivity. According to the transportation of goods by train, truck or airplane, different means of loading-unloading are used such as crane, crate, pallet etc. which you may need to take advantage of. The loading height can also be used to take into account the trajectory and swing of the train and truck. Personal training seminars can be organized; packaging can be standardized to reduce wait and ease of transport. Aids can be used to remove and stock large packages.

It has been determined that the problems experienced by the companies in the procurement process are mainly caused by the shortcomings of the suppliers on the after-sales service and guarantee. This problem may be due to insufficient promises made prior to purchase, and due to damage caused by out of warranty.

The choice of supplier can be made more rigorous in order to resolve this problem and the purchase contract can be made by writing. Supplier selection can be made more professional by considering delivery on time and after-sales service of the supplier. Negotiation of the purchase agreement by non-professional persons may result in invalidation of the agreement and cause the firm to suffer financial difficulties. For this reason, examining all the suppliers in the sector and making supplier selection and purchasing contracts by specialists can reduce the problems experienced. In the procurement process, there are also problems such as the lack of suitable materials and technology to meet the needs and the delay of deliveries. These problems can be caused by the fact that sector and supplier research hasn't been properly. For this reason, it is possible to make the selection of suitable materials and suppliers by drawing out the sector.

All companies participating in the survey are experiencing problems arising from the slow execution of transactions in customs operations. Shifts in the overtime system can be applied and overtime rates can be reduced. Parallel to the transaction volume of the customs administration, the number of personnel can be made sufficient. Time losses can be avoided by improving the technical possibilities at border gates. It may also be useful to intensify initiatives at the international border level on border gates.

Other problems that companies have experienced in logistics sector are bureaucratic problems and excess of legal regulations, lack of development of intermodal transportation in Turkey, excessive investment costs, lack of theoretical training in the field, and lack of necessary logistic infrastructure investments in the regions. Some of the procedures in the regulations can be simplified, the required documents can be reduced and the companies can be made aware about the regulations.

Plans and programs can be developed to enhance the human resources that will produce economic solutions by enriching the training of the workforce so that it is not limited to a single mode. For the logistics industry to advance, it may need to increase investment reduction applications and incentive premiums. Due to the lack of necessary logistic infrastructure investments in the region, it may not be possible to benefit from logistical advantages at the desired level and sustainability. For this reason, regions can be made logically attractive by considering the world examples of the experience and knowledge that exists in logistics and the potential of geographical proximity advantages.

Firms can experience problems due to the lack of theoretical training and lack of qualified personnel. In order to prevent these problems from happening, those who will work in the logistics sector may need vocational training and planned trainings may be given by the company.

* This study was derived from master's thesis written at The University of Gaziantep Institute of Social Sciences Department of Business Administration.

** This study was a submission on INTCESS 2017- 4th INTERNATIONAL CONFERENCE ON EDUCATION AND SOCIAL SCIENCES

\section{REFERENCE LIST}

Aydın, G.T., Öğüt, K.S. (2008a). What is a Logistic Village?. 2. Internation Railway Sempozium, Railway Convention Bulletin Book. 15-17 October 2008, p:1439-1448, İstanbul.

Babacan, M. (2003). Development and Competitiveness Vision of the Logistics Sector in our Country. Ege 
Akademic Review, 3(12):10.

Bilgin, N. (2006). Content Analysis Techniques and Case Studies in Social Sciences. Ankara: Siyasal Bookstore.

Gültaş, P. and Yücel, M. (2015). Green Logistics: Green Transportation Services Malatya Metropolitan Municipality Example, Akademik Yaklaşımlar Magazine, 6 (2) p.70-83.

Gür, S. (2009). Logistics Sector Problems and Solution Suggestions. Master Thesis, Gaziantep University Social Sciences Institute, Gaziantep.

Gürdal, S. (2006). Turkey’s Logistics Sector Infrastructure Analysis. ITO Print No: 2006-14.

Koban, E. and Keser, H. (2007). Logistics in Foreign Trade. 1.Edition, Ekin Publishing and Distribution, Bursa.

Tanyaş, M. (2006). Strategy and Solution Proposals for the Turkish Logistics Sector. Atılım University, Ankara.

Tanyaş, M. (2016). Logistics Villages-Centers, http://www.somutstrateji.com/lojistik-koylermerkezler/, (3.03.2016).

Tuna, O. (2001). Logistics and Maritime Strategies for Turkey: International and Regional Identifiers. Dokuz Eylül University Social Sciences Institute Magazine, 3(2), 194-208, İzmir.

Tutar, E., Tutar, F. and Yetişen, H. (2009). A Comparative Analysis of the Development Level of Logistics Sector in Turkey with Selected EU Countries (Romania and Hungary).KMU IBBF Magazine 11 (17), 190-216.

Yıldııım, A. and Şimşek, H. (2008). Qualitative research methods in the social sciences. Seçkin Press, 7.Edition, Ankara. 